\title{
Effect of grain raw materials on the quality characteristics of 'Kaoliang' spirit
}

\author{
Hwa-Rang Seo ${ }^{1 \neq}$, Seok-Tae Jeong ${ }^{1 \neq}$, Bo-Ra Iim ${ }^{1}$, JI-Eun Kang ${ }^{2}$, \\ Heui-Yun Kang ${ }^{1 *}$, Sun-Il Yun ${ }^{3 *}$ \\ ${ }^{l}$ Fermented and Food Science Division, National Institude of Agriculture Sciences, Jeonju 55365, Korea \\ ${ }^{2}$ Planning \& Coordination Division, National Institude of Agriculture Sciences, Jeonju 55365, Korea \\ ${ }^{3}$ Department of Food Science and Technolgy, Chonbuk National University, Jeonju 54896, Korea
}

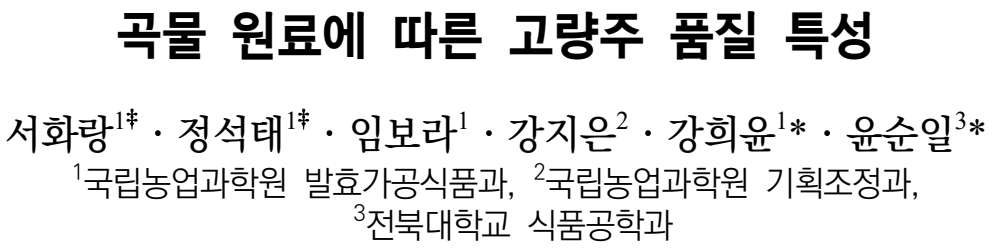

Abstract

This study was caried out to investigate the quality characteristics of 'Kaoliang' spirit by grain materials for developing the Korean-style 'Kaoliang' spirit. Each grain was crushed for solid fermentation, and re-fermentation was performed three times in total. There was no significant difference in temperature during solid fermentation by different grains, but it rose to up to $31^{\circ} \mathrm{C}$ until the first two days of fermentation, and then the fermentation was completed while maintaining $27^{\circ} \mathrm{C}$. Agglomeration occurred in solid fermentation using wheat, resulting in lower work efficiency than other grains. The total acids increased after fermentation, and was the highest at $0.77 \%$ in distilled spirit using sorghum, and the major organic acids were lactic acid and acetic acid. A lot of glycerol and glucose were detected, and after three re-fermentation, all sugars were converted to ethanol. Through three re-fermentation, ethanol was the highest in distilled spirit using com and barley. The volatile compounds, ethyl acetate, ethyl butyrate, and ethyl lactate, were detected at the high level in distilled spirit using sorghum, and the highest ethyl caproate component in using wheat. Therefore, this study proposed to use the mixed grain materials, sorghum and wheat, in order to increase the production of ethyl caproate, the main aroma compound in 'Kaoliang' spirit.

Keywords : solid fermentation, sorghum, 'Kaoliang' spirit

\section{서 론}

고량주는 브랜디, 위스키, 보드카, 진, 럼과 같이 세계적으 로 유명한 증류주 중 하나이다. 고량주는 일반적으로 수수 단 독 또는 옥수수, 쌀, 밀, 완두콩, 등의 곡류를 혼합하여 만들
어진다. Jiuqu라 불리는 중국의 누룩으로 알려진 발효제로 곡 물과 혼합하여 당화와 발효를 동시에 수행하여 에탄올과 향 기성분을 생성한다(Liu와 Sun, 2018).

고체발효 증류주의 발효 방법에는 누룩의 종류를 다르게 하여 생산하는데 대국주, 소국주, 부국주 등이 있다. 대국주

\footnotetext{
${ }^{*}$ Corresponding author. Heui-Yun Kang. E-mail : albert@korea.kr, Phone : +82-63-238-3621, Fax : +82-63-238-3843

Sun-Il Yun. E-mail : siyun@jbnu.ac.kr, Phone :+82-63-270-2566, Fax :+82-63-270-2527

${ }^{\ddagger}$ These authors contributed equally to this work.

Received 12 October 2021; Revised 02 November 2021; Accepted 08 November 2021.

Copyright (C) The Korean Society of Food Preservation.

This is an Open Access article distributed under the terms of the Creative Commons Attribution Non-Commercial License (http://creativecommons.org/licenses/by-nc/4.0) which permits unrestricted non-commercial use, distribution, and reproduction in any medium, provided the original work is properly cited.
} 
는 원료로 밀, 보리, 완두 등을 사용하여 누룩을 만들어 당화, 발효시켜 증류하여 생산한다. 소국주는 곰팡이균을 쌀, 밀기 울 등에 접종하여 누룩을 만들어 당화, 발효시켜 증류하여 생 산한다. 부국주는 원료로 밀기울을 사용하여 필요한 균을 접 종하여 누룩을 만들어 여기에 효모균을 보완하여 당화, 발효 시켜 증류하여 생산한다(Lee 등, 2015).

중국의 백주는 곡물들을 원료로 사용하며, 곡물들은 당화, 발효, 증류를 거쳐 최종적으로 제품을 생산하게 된다. 일반적 으로 백주의 주 원료로서 수수가 사용되며, 수수로 만드는 백 주를 ‘고량주’라고도 잘 알려져 있다. 백주 산업계에서 수수 증류주는 향기롭고, 옥수수 증류주는 달고, 보리 증류주는 톡 쏘는 맛으로 인식되고 있는데, 이는 각기 다른 곡물로 만든 백주와의 차이점이다(Han 등, 2017). 현대 백주의 생산에서 는 수수뿐만 아니라 옥수수, 쌀, 밀 등의 곡물들도 활용되고 있다(Yu 등, 2006; Zamora 등, 2002).

국내 고량주의 수입은 2010-2020년 사이 꾸준하게 증가하 는 추세를 보이며 2010년 2.352천 달러에서 2020년 12,160천 달러로 $417 \%$ 의 상승률을 보이며, 이는 국내 고량주 소비가 증가하였음을 알 수 있다(KATI, 2021). 국내 고량주에 대한 연구로는 고량주의 증류 후 나온 술지게미를 활용하여 만든 식초 연구가 수행된 바 있다(Kim과 Jo, 1981). 최근 국내 고량 주 소비가 증가함에도 불구하고 제조 방법과 원료에 대한 품 질 특성 연구는 전무한 실정이다. 따라서 본 연구에서는 국내 에서 생산된 고량주에 대한 곡물 원료가 고량주의 품질 특성 에 미치는 영향을 알아보기 위해 수수, 옥수수, 밀, 보리, 조를 이용하여 직접 고체발효를 하고, 증류하여 곡물에 따른 특성 차이를 분석하였으며, 그 결과를 보고하고자 한다.

\section{재료 및 방법}

\section{실험재료}

본 실험에 사용된 재료로서 수수(Daeguhabin farm, Daegu, Korea), 옥수수(Esinsun farm, Gangwon, Korea), 밀 (Seumnye rice mill, Gumi, Korea), 보리(Sohwa farm, Yecheon, Korea), 조(Sohwa farm, Yecheon, Korea)를 사용하였다. 발효 보조 제로는 왕겨(Leeseo rice mill, Wanju, Korea)를 사용하였다. 발효제로서 사용된 누룩은 산성누룩(Sanseongnuruk Co., Busan, Korea)을 사용하였다.

\section{고체발효 및 증류}

고체발효 방법은 Fig. 1과 같은 방식으로 진행되었다. 곡물 (수수, 옥수수, 밀, 보리, 조)을 각 곡물입자를 가볍게 분쇄하 였다. 분쇄된 곡물에 건조 원료의 무게대비 $40 \%$ 수분을 첨가 하고 30 분간 흡수시켰다. 수분을 흡수한 각 곡물에 건조 원료

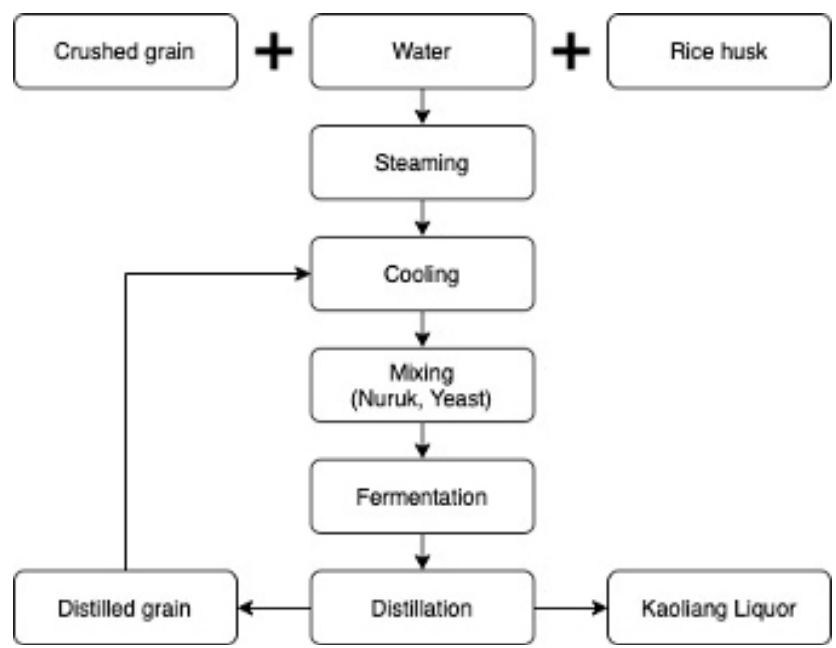

Fig. 1. Process for making 'Kaoliang' spirit by solid fermentation.

의 $40 \%$ 왕겨를 혼합하여 40 분간 증자하였다. 증자한 혼합물 을 $25^{\circ} \mathrm{C}$ 이하의 온도가 될 때까지 냉각시켰다. 냉각된 혼합물에 각 원료의 무게대비 $10 \%$ 의 누룩, $0.1 \%$ 의 효모, $50 \%$ 의 물을 혼 합하여 $27^{\circ} \mathrm{C}$ 의 발효실에서 14 일간 발효를 진행하였다. 발효를 진행하면서 자동 온도 측정 센서(hobo 4-channel thermocouple logger, Onset Computer Co, Massachusetts, USA)를 사용하 여 고체발효 중 중심부의 온도 변화를 1 시간 간격으로 측정 되도록 설정하여 온도 변화를 측정하였다. 발효가 완료된 각 혼합물을 증류하여 각 $500 \mathrm{~mL}$ 씩 받아내었다.

\section{고체발효 작업성}

재료배합 시 작업성은 시험처리자가 판단하여 나타내었다. $+1+$ 는 재료 배합이 용이한 상태이며, ++ 는 재료 배합하는 데 큰 어려움이 없는 정도이고, + 는 재료배합이 어려운 상태를 표시하였다.

\section{고체발효 술덧 분석}

분석시료는 고체발효 술덧을 균일하게 고루 섞어 $20 \mathrm{~g}$ 을 채취하여 증류수 $100 \mathrm{~mL}$ 와 혼합하여 1 시간 추출을 진행하였 다. 추출된 시료는 여과지에 걸러서 $\mathrm{pH}$, 총산, 유리당, 유기 산 분석에 사용하였다.

\section{$\mathrm{pH}$ 및 총산 측정}

$\mathrm{pH}$ 는 $\mathrm{pH}$ meter(Orion 3 star, Thermo Fisher Scientific Inc., Waltham, Massachusetts, USA)로 상온에서 측정하고, 총산은 주류분석규정(National Tax Service Liquor License Support Center, 2017)에 따라 각 시료 $10 \mathrm{~mL}$ 를 중화시키는 데 필요한 $0.1 \mathrm{~N} \mathrm{NaOH}$ (Yakuripure chemicals Co., LTD, Kyoto, Japan) 용액의 소비량을 citric acid로 환산하여 나타 
내었다(Park 등, 2017).

\section{유리당 분석}

유리당 분석은 HPLC(e-2695, Waters Co., Milford, Massachusetts, USA)를 이용하였으며 post column 방법을 활용하 였다. 유리당 분석용 column은 Asahipak NH2P-50 4E (Shodex F7630001 4.6×250 mm)로 분석하였다. 이동상은 $75 \%$ acetonitrile(Mallinckrodt Baker Inc., Phillipsburg, New jersey, USA)를 사용하였고, flow rate $1.0 \mathrm{~mL} / \mathrm{min}$, column oven $35^{\circ} \mathrm{C}$, injection volume은 $10 \mu \mathrm{L}$ 로 설정하여 RI detector (2414, Waters Co., Milford. Massachusetts, USA)로 검출하 였다(Park 등, 2017). 시료는 여과 $(0.2 \mu \mathrm{L}$, Millipore Co., Cork, Ireland)하여 사용하였다.

\section{유기산 분석}

유기산 분석은 HPLC(LC-20A, Shimadzu Co., Kyoto, Japan)를 이용하였으며, post column 방법을 활용하였다. 유 기산 분석용 column은 TSK gel ODS- $100 \mathrm{~V}(5 \mu \mathrm{m}, 4.6 \mathrm{~mm}$ $\mathrm{ID} \times 25.0 \mathrm{~cm}$, Tosoh Co., Tokyo, Japan)로 분석하였다. 이동 상은 $8 \mathrm{mM}$ perchloric acid(Kanto chemical, Tokyo, Japan) 를 이용하였으며, 반응용액 $0.2 \mathrm{mM}$ bromothymol blue (Sigma Chemical Co., St. louis, Missouri, USA), $15 \mathrm{mM}$ Na2HPO4(Sigma Chemical Co., St. louis, Missouri, USA), $7 \mathrm{mM} \mathrm{NaOH}$ (Sigma Chemical Co., St.louis, Missouri, USA) 와 반응한 후 UV $440 \mathrm{~nm}$ 에서 검출하였다. Flow rate는 이동 상 $1 \mathrm{~mL} / \mathrm{min}$, 반응용액 $1 \mathrm{~mL} / \mathrm{min}$, column oven의 온도는 $40^{\circ} \mathrm{C}$, 반응용액의 온도는 $25^{\circ} \mathrm{C}$ 로 하였다( $\mathrm{Kim}$ 등, 2017). 시 료는 여과 $(0.2 \mu \mathrm{m}$, Millipore Co., Cork, Ireland)한 후 사용하 였다.

\section{고체발효 증류주 분석}

증류주 시료는 고체발효가 완료된 술덧을 스테인레스 증 류기(YD-200, Yada Intelligent Co., Yeongju, China)를 사용 하여 증류액 $500 \mathrm{~mL}$ 를 받아 분석에 사용하였다.

\section{알코올 측정}

알코올분 측정은 주류 용 진동식 밀도계(Digital Alcohol Meter DA-155, KEM Kyoto electronics, Kyoto, Japen)를 $15^{\circ} \mathrm{C}$ 로 보정하고, 시료를 2-4 mL를 주입하여 알코올 함량 $(\%, v / v)$ 을 측정하였다.

\section{향기성분 분석}

고체발효 증류주의 분석은 gas chromatograph(Shimadzu GC-2010, Shimadzu Co., Ltd., Kyoto, Japan)를 사용하였으
며 column은 Nukol(30 $\mathrm{m} \times 0.32 \mathrm{~mm} \times 0.25 \mu \mathrm{m}$ film thickness, Spelico, USA)과 oven의 온도는 $50^{\circ} \mathrm{C}$ 에서 $3{ }^{\circ} \mathrm{C} / \mathrm{min}$ 로 상승시 켜 $200^{\circ} \mathrm{C}$ 에서 10 분간 머물렀다. 운반기체는 helium을 사용하 여 $10 \mathrm{~cm} / \mathrm{sec}$ 로 유속을 설정하였으며 주입량은 $1 \mu \mathrm{L}$ 이 다. FID(flame ionization detector)로 시료를 검출하였고 이때 injection port와 $\mathrm{FID}$ 의 온도는 각 $220^{\circ} \mathrm{C}$ 로 하였다(Song 등, 2020). 표준물질은 n-Pentane:ethyl ether(1:1)에 용해시켜 $0.125-10 \mu \mathrm{g} / \mathrm{mL}$ 범위의 표준용액을 조제하여 peak area로부 터 검량선을 작성하여 정량하였다.

\section{통계처리}

통계처리는 각 분석항목에 대하여 3 회 반복 측정하여 얻은 결과를 SPSS 18.0 통계 프로그램을 이용하였다. 각 품종별 품질 특성에 대하여 처리구간의 유의적인 차이를 알아보기 위해 일원배치 분산분석(One-way ANOVA)을 실시하였고, 실험구간의 통계적 유의성은 $\mathrm{p}<0.05$ 수준에서 Duncan's multiple range test의 다중범위 검정을 실시하였다.

\section{결과 및 고찰}

\section{곡류 종류별 고체발효 작업성}

각 곡물 종류별 고체발효 과정에 있어서 작업성은 Fig. 2 와 Table 1에서 보는 것과 같다. 곡물의 고체발효 과정에서 재료들의 혼합 시 Fig. 2(A)와 2(B)를 비교해서 보았을 때 뭉 침 현상이 있어 작업능률이 떨어진다는 것을 알 수 있다. 보 리의 경우 재발효 시 질척이는 현상이 발생하여 혼합의 어려 움이 있었다. 따라서 뭉침 현상이 있는 곡류는 그렇지 않은 곡류와 혼합하여 사용하는 것이 유리할 것으로 생각된다.

\section{고체발효 술덧의 온도 변화}

각 곡물 종류별로 고체발효 술덧의 온도 변화는 중심부를 측정하였으며, 그 결과 Fig. 3에 나타내었다. 곡물 종류간의 큰 차이는 없었으며 발효 초기 2 일 사이에 온도가 최대 $31^{\circ} \mathrm{C}$ 까지 상승하며 점차 외기 온도인 $27^{\circ} \mathrm{C}$ 를 유지하였다. 호기적 발효는 혐기적 발효에 비해 약 15 배의 에너지를 낸다고 알려 져 있다(Margalit, 1997). 따라서 각 곡물의 초기 2일 사이 온 도가 급격히 상승하는 것은 술덧 공극 사이에 있는 산소에 의한 호기적 발효에 의한 발열로 생각된다.

\section{$\mathrm{pH}$ 및 총산}

곡물 원료(수수, 옥수수, 밀, 보리, 조)를 다르게 하여 제조 한 고체발효 술덧의 전, 후 $\mathrm{pH}$ 는 다음 Table 2 에서 보는 것과 같다. 곡물 전체적으로 발효 전, 후의 $\mathrm{pH}$ 는 감소하였다. 발효 전 수수와 조를 사용한 고체발효 술덧에서 $\mathrm{pH}$ 는 $6.52,6.56$ 으 
(A)

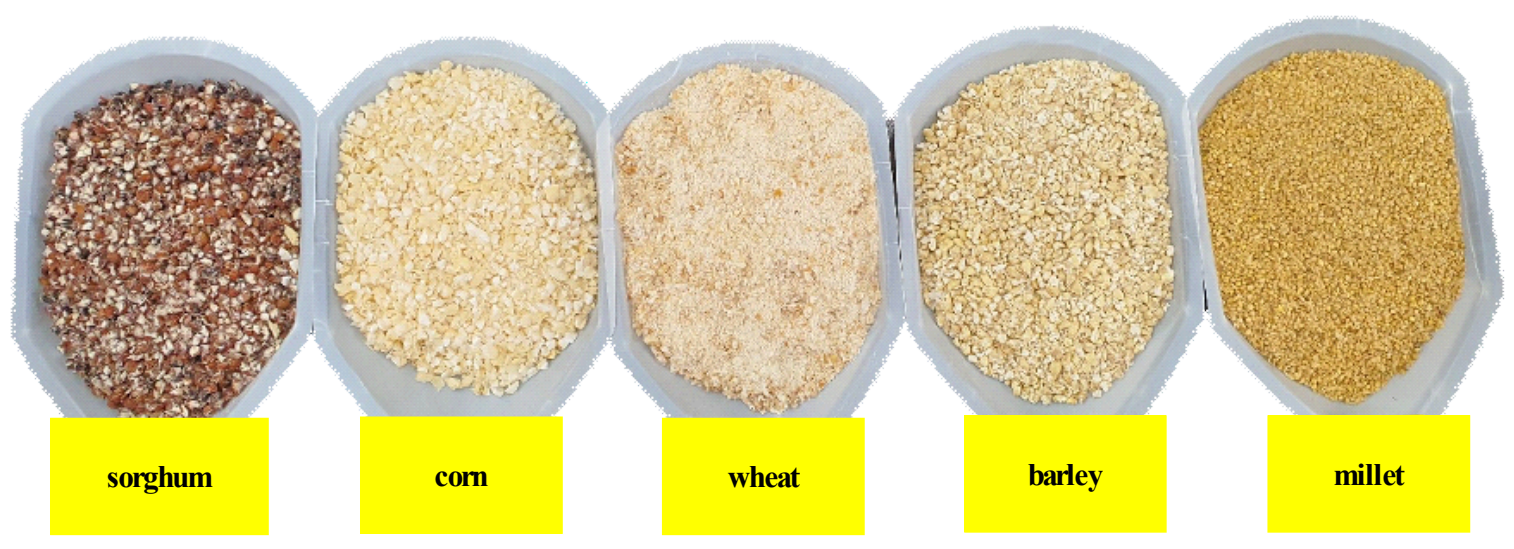

(B)
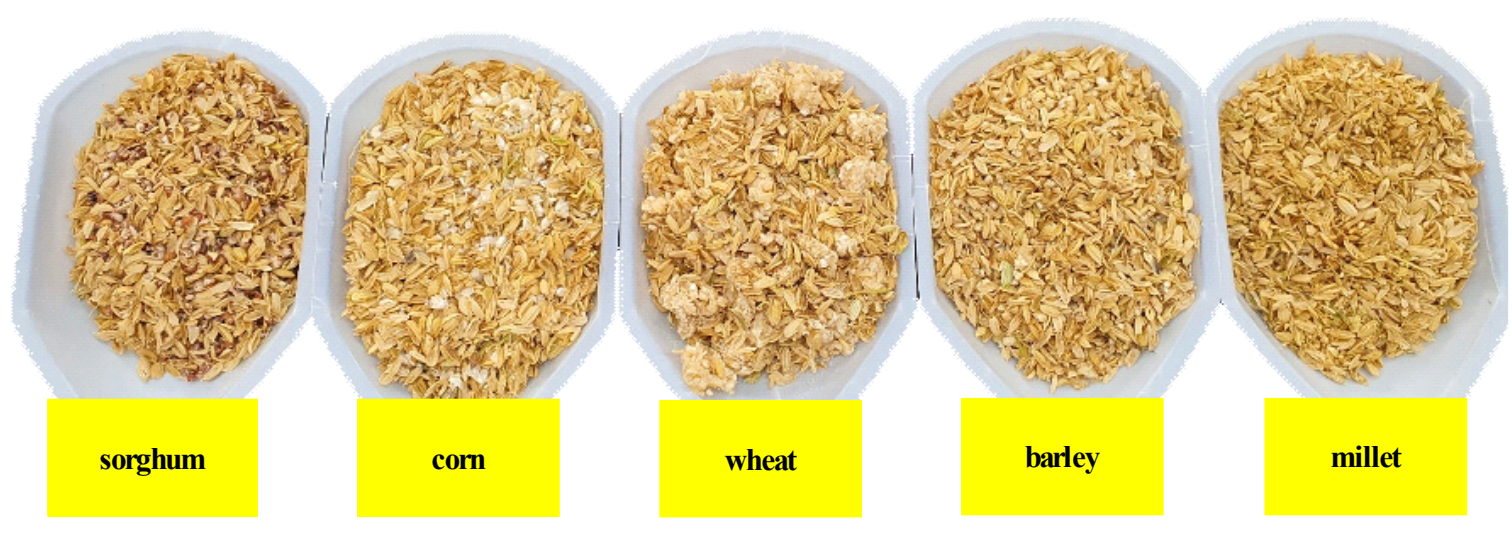

Fig. 2. Pictures of different types of grains (from the left, sorghum, corn, wheat, barley, millet).

(A) Grinding grains. (B) A mixture with grains and rice husk.

Table 1. The workability at mixing treatment of materials, grain and nuruk

\begin{tabular}{cccccc}
\hline $\begin{array}{c}\text { The number of } \\
\text { fermentation times }\end{array}$ & Sorghum & Corn & Wheat & Barley & Millet \\
\hline 1st & $+++^{*}$ & +++ & + & ++ & ++ \\
2nd & ++ & ++ & + & + & + \\
3rd & ++ & ++ & + & ++ \\
\hline
\end{tabular}

*+1, very good; ++, good; +, bad.

로 가장 높고, 발효 후 수수를 사용한 고체발효 술덧에서 $\mathrm{pH}$ 는 4.65로 가장 낮았으며 $\mathrm{pH}$ 변화량이 가장 크게 나타나는 특징을 보였다. 발효 중 발생하는 $\mathrm{CO}_{2}$ 는 발효액 속에 녹아 약산성을 띄기 때문에 $\mathrm{pH}$ 가 감소하게 된다(Margalit, 1997). 알코올 발효 시 $\mathrm{pH}$ 의 감소는 효모의 알코올 발효를 안정적으 로 하게하며, 세균의 증식을 억제시키는 등 발효에 크게 영향 을 미치는 것으로 보고한 바 있다(Kim과 Yi, 2010).
원료나 발효제로 사용하는 누룩에는 다양한 미생물이 존 재하며, 특히 막걸리 발효 도중 효모, 젖산균의 증가로 인해 생성되는 유기산에 의해 생성된다고 알려져 있다. 총산은 휘 발성 향기성분과 직접관련이 되어 있고, 보존성에도 영향을 미친다(Lee 등, 2009). 각 곡물 원료를 이용한 고체발효 술덧 의 발효 전, 후의 총산 함량의 비교는 Table 2에서 보는 것과 같다. 곡물 전체적으로 발효 전, 후 총산의 함량은 크게 증가 


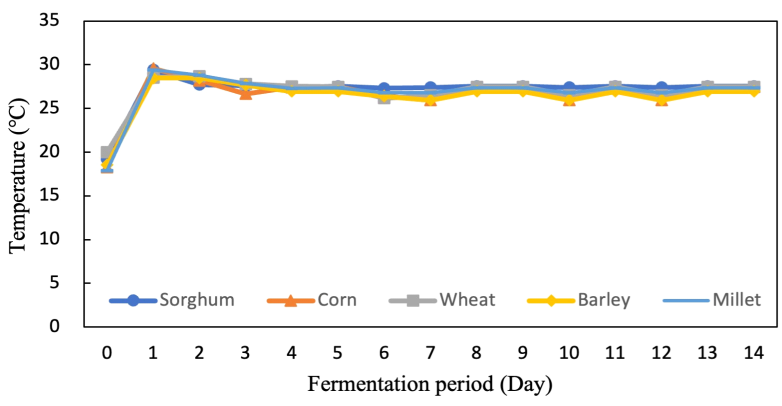

Fig. 3. The temperature changes during the solid fermentation of different grain materials.

하였다. 발효 전 수수와 옥수수의 고체발효 술덧에서 각각 $0.15 \%, 0.16 \%$ 로 가장 높고, 발효 후 수수의 고체발효 술덧에
서 $0.77 \%$ 로 가장 높은 총산 함량을 나타내었다.

\section{유리당}

술덧의 유리당 함량을 조사한 결과 Table 3 과 같이 발효 전, 후 유리당은 glycerol, fructose, glucose 3종이 검출되었 고, sucrose, maltose는 검출되지 않았다 발효 전, 후로 곡물 전체적으로 fructose는 감소하였고 glycerol이 증가하였다. 발 효 전 옥수수를 사용하여 만든 고체발효 술덧에서 Fructose 함량이 $406 \mathrm{mg} / \mathrm{L}$ 로 가장 높게 나왔으며, 조를 사용한 고체발 효 술덧에서 $234.81 \mathrm{mg} / \mathrm{L}$ 로 가장 낮게 나타났다. glucose의 함량은 보리를 이용하여 만든 고체발효 술덧에서 $6,752.81$ $\mathrm{mg} / \mathrm{L}$ 로 가장 높게 나왔으며, 수수를 사용한 고체발효 술덧에 서 $2,308.17 \mathrm{mg} / \mathrm{L}$ 로 가장 낮게 나타났다. 발효 후 glycerol 함량이 조를 사용하여 만든 고체발효 술덧에서 $356.57 \mathrm{mg} / \mathrm{L}$

Table 2. pH and total acid of first solid-fermented mesh depending on grain materials

\begin{tabular}{|c|c|c|c|c|}
\hline \multirow{2}{*}{ Grains } & \multicolumn{2}{|c|}{$\mathrm{pH}$} & \multicolumn{2}{|c|}{ Total Acid (\%) } \\
\hline & Before & After & Before & After \\
\hline Sorghum & $6.52 \pm 0.04^{\mathrm{a} 1)}$ & $4.65 \pm 0.07^{\mathrm{d}}$ & $0.15 \pm 0.01^{\mathrm{a}}$ & $0.77 \pm 0.05^{\mathrm{a}}$ \\
\hline Corn & $6.41 \pm 0.04^{\mathrm{b}}$ & $5.02 \pm 0.04^{\mathrm{c}}$ & $0.16 \pm 0.01^{\mathrm{a}}$ & $0.72 \pm 0.03^{\mathrm{b}}$ \\
\hline Wheat & $6.43 \pm 0.03^{\mathrm{b}}$ & $5.07 \pm 0.06^{\mathrm{c}}$ & $0.10 \pm 0.01^{\mathrm{c}}$ & $0.53 \pm 0.02^{\mathrm{d}}$ \\
\hline Barley & $6.15 \pm 0.04^{\mathrm{c}}$ & $5.30 \pm 0.03^{\mathrm{b}}$ & $0.11 \pm 0.01^{\mathrm{c}}$ & $0.51 \pm 0.01^{\mathrm{d}}$ \\
\hline Millet & $6.56 \pm 0.06^{\mathrm{a}}$ & $5.58 \pm 0.02^{\mathrm{a}}$ & $0.13 \pm 0.01^{\mathrm{b}}$ & $0.58 \pm 0.02^{\mathrm{c}}$ \\
\hline
\end{tabular}

${ }^{1)}$ Mean \pm SD ( $\left.n=3\right)$ within each column followed by different letters is significantly different $(\mathrm{p}<0.05)$.

Table 3. Free sugar of first solid-fermented mesh depending on grain materials

\begin{tabular}{|c|c|c|c|c|c|c|}
\hline Free sugar $(\mathrm{mg} / \mathrm{L})$ & First fermentation & Sorghum & Corn & Wheat & Barley & Millet \\
\hline \multirow{2}{*}{ Glycerol } & Before & $\mathrm{ND}^{1)}$ & ND & ND & ND & ND \\
\hline & After & $122.4 \pm 36.3^{\mathrm{c} 2)}$ & $263.4 \pm 33.0^{\mathrm{b}}$ & $40 \pm 25.8^{\mathrm{d}}$ & $163.7 \pm 41.1^{\mathrm{c}}$ & $356.6 \pm 27^{\mathrm{a}}$ \\
\hline \multirow{2}{*}{ Fructose } & Before & ND & $406 \pm 47.2^{\mathrm{a}}$ & $262.2 \pm 69.1^{\mathrm{bc}}$ & $329.6 \pm 27.2^{\mathrm{ab}}$ & $234.8 \pm 19^{c}$ \\
\hline & After & ND & ND & ND & ND & ND \\
\hline \multirow{2}{*}{ Glucose } & Before & $2,308.1 \pm 257.1^{\mathrm{e}}$ & $4,266.2 \pm 487.4^{\mathrm{c}}$ & $2,981.3 \pm 353.4^{\mathrm{d}}$ & $6,752.8 \pm 444.7^{\mathrm{a}}$ & $5,558.2 \pm 44.2^{\mathrm{b}}$ \\
\hline & After & ND & $1,123.4 \pm 246.6$ & $5,476.7 \pm 776.4$ & $7,662.8 \pm 223.6$ & $3,001.9 \pm 12.6$ \\
\hline \multirow{2}{*}{ Sucrose } & Before & ND & ND & ND & ND & ND \\
\hline & After & ND & ND & ND & ND & ND \\
\hline \multirow{2}{*}{ Maltose } & Before & ND & ND & ND & ND & ND \\
\hline & After & ND & ND & ND & ND & ND \\
\hline
\end{tabular}

1) Not detected.

${ }^{2)}$ Mean \pm SD $(n=3)$ within each column followed by different letters is significantly different $(p<0.05)$. 
로 가장 높았으며, 밀을 사용한 고체발효 술덧에서 39.99 $\mathrm{mg} / \mathrm{L}$ 로 가장 낮게 나타났다. glucose 함량은 보리를 사용하 여 만든 고체발효 술덧에서 $7,662.8 \mathrm{mg} / \mathrm{L}$ 로 가장 높고, 옥수 수를 사용한 고체발효 술덧에서 $1,123.41 \mathrm{mg} / \mathrm{L}$ 로 가장 낮게 나타났다. 총 3 회 재발효 시 유리당은 검출되지 않으며, 3 회 이상의 재발효 시에는 원료의 추가가 필요할 것으로 보인다. 술덧에서 유리당은 원료로 사용한 곡물이 누룩의 당화효소에 의해 분해되어 생성되고(Lee 등, 2010), 이렇게 생성된 당분 이 발효과정 중에 효모에 의해 소비되지 않고 남은 잔당이라 고 할 수 있다. 따르면 당분은 증류과정 중에 고온의 열에 의
해 furfural을 형성함으로서 증류주의 향기에 영향을 미치는 것으로 알려져 있다(Lee 등, 2014).

\section{유기산}

술덧의 유기산 함량은 다음 Table 4 를 보는 것과 같다. 1 차 발효 시 수수를 사용한 고체발효 술덧에서 lactic acid, acetic acid, succinic acid의 함량이 각 $75.26 \mathrm{mg} / \mathrm{L}, 45.52 \mathrm{mg} / \mathrm{L}, 40$ $\mathrm{mg} / \mathrm{L}$ 로 다른 대조군에 비해 높게 검출되는 특징을 보였다. 밀, 보리, 조에서는 수수와 옥수수에서는 검출되지 않는 citric acid의 성분이 검출되는 특징을 보였으며 보리와 조의 대조

Table 4. Organic acids of solid-fermented mesh depending on grain materials

\begin{tabular}{|c|c|c|c|c|c|c|}
\hline $\begin{array}{l}\text { Organic acids } \\
\text { (mg/L) }\end{array}$ & $\begin{array}{l}\text { The number of } \\
\text { fermentation times }\end{array}$ & Sorghum & Corn & Wheat & Barley & Millet \\
\hline \multirow{3}{*}{ Malic acid } & $1 \mathrm{st}$ & $\mathrm{ND}^{1)}$ & ND & ND & $10.1 \pm 1.03^{\mathrm{a}}$ & ND \\
\hline & 2nd & ND & ND & $1.22 \pm 0.32^{\mathrm{a}}$ & ND & ND \\
\hline & $3 \mathrm{rd}$ & $\mathrm{ND}$ & $0.55 \pm 0.95^{\mathrm{a}}$ & $2.84 \pm 1.28^{\mathrm{a}}$ & $1.2 \pm 0.03$ & ND \\
\hline \multirow{3}{*}{ Ascorbic acid } & $1 \mathrm{st}$ & $\mathrm{ND}$ & ND & ND & ND & ND \\
\hline & 2nd & ND & ND & $8.59 \pm 0.25^{\mathrm{a}}$ & ND & ND \\
\hline & $3 \mathrm{rd}$ & ND & ND & $5.7 \pm 0.39^{\mathrm{a}}$ & $6.05 \pm 0.57^{\mathrm{a}}$ & $9.73 \pm 16.86^{\mathrm{a}}$ \\
\hline \multirow{3}{*}{ Lactic acid } & $1 \mathrm{st}$ & $75.26 \pm 9.26^{\mathrm{a} 2)}$ & $63.13 \pm 19.8^{\mathrm{a}}$ & $27.28 \pm 3.59^{b}$ & $28.32 \pm 1.37^{b}$ & $27.41 \pm 5.11^{\mathrm{b}}$ \\
\hline & 2 nd & $116.84 \pm 56.11^{\mathrm{a}}$ & $95.87 \pm 34.35^{\mathrm{ab}}$ & $51.78 \pm 23.59^{\mathrm{b}}$ & $43.59 \pm 14.03^{b}$ & $92.33 \pm 14.17^{\mathrm{ab}}$ \\
\hline & $3 \mathrm{rd}$ & $82.05 \pm 45.89^{\mathrm{a}}$ & $89.98 \pm 12.17^{\mathrm{a}}$ & $63.31 \pm 17.84^{\mathrm{a}}$ & $98.26 \pm 3.21^{\mathrm{a}}$ & $71.28 \pm 9.69^{\mathrm{a}}$ \\
\hline \multirow{3}{*}{ Acetic acid } & $1 \mathrm{st}$ & $45.52 \pm 9.08^{\mathrm{a}}$ & $28.69 \pm 6.73^{b}$ & $15.33 \pm 2.85^{\mathrm{b}}$ & $20.22 \pm 1.11^{\mathrm{bc}}$ & $25.7 \pm 2.89^{c}$ \\
\hline & 2nd & $143.1 \pm 157.45^{\mathrm{a}}$ & $52.94 \pm 5.31^{\mathrm{a}}$ & $28.51 \pm 16.83^{\mathrm{a}}$ & $40.21 \pm 15.25^{\mathrm{a}}$ & $83.43 \pm 63.09^{\mathrm{a}}$ \\
\hline & $3 \mathrm{rd}$ & $103.63 \pm 64.1^{\mathrm{a}}$ & $62.33 \pm 9.25^{\mathrm{a}}$ & $69.77 \pm 18.79^{\mathrm{a}}$ & $67.47 \pm 25.46^{\mathrm{a}}$ & $52.21 \pm 12.3^{\mathrm{a}}$ \\
\hline \multirow{3}{*}{ Citric acid } & $1 \mathrm{st}$ & $\mathrm{ND}$ & ND & $4.89 \pm 2.8^{\mathrm{b}}$ & $16.08 \pm 2.3^{\mathrm{a}}$ & $18.9 \pm 0.84^{\mathrm{a}}$ \\
\hline & 2nd & $\mathrm{ND}$ & ND & $1.16 \pm 0.66^{\mathrm{a}}$ & $1.73 \pm 2.99^{\mathrm{a}}$ & ND \\
\hline & $3 \mathrm{rd}$ & $\mathrm{ND}$ & ND & $1.22 \pm 0.29^{\mathrm{a}}$ & $0.33 \pm 0.39^{\mathrm{b}}$ & ND \\
\hline \multirow{3}{*}{ Succinic acid } & $1 \mathrm{st}$ & $40 \pm 2.06^{\mathrm{a}}$ & $31.26 \pm 7.65^{b}$ & $11.5 \pm 0.43^{\mathrm{d}}$ & $16.45 \pm 2.22^{\mathrm{cd}}$ & $18.92 \pm 1.53^{\mathrm{c}}$ \\
\hline & 2nd & $40.87 \pm 6.55^{\mathrm{a}}$ & $27.06 \pm 12.31^{\mathrm{b}}$ & $17.53 \pm 1.35^{\mathrm{b}}$ & $12.84 \pm 3.8^{\mathrm{b}}$ & $22.45 \pm 7.74^{\mathrm{b}}$ \\
\hline & $3 \mathrm{rd}$ & $24.66 \pm 8.18^{\mathrm{a}}$ & $16.13 \pm 3.88^{\mathrm{ab}}$ & $19.92 \pm 1.48^{\mathrm{ab}}$ & $14.38 \pm 0.28^{\mathrm{b}}$ & $22.65 \pm 6.04^{\mathrm{ab}}$ \\
\hline \multirow{3}{*}{ Fumaric acid } & $1 \mathrm{st}$ & $\mathrm{ND}$ & ND & ND & ND & ND \\
\hline & 2nd & $\mathrm{ND}$ & ND & $0.58 \pm 1^{\mathrm{a}}$ & ND & ND \\
\hline & $3 \mathrm{rd}$ & $\mathrm{ND}$ & ND & $1.17 \pm 1.01^{\mathrm{a}}$ & $0.67 \pm 1.17^{\mathrm{a}}$ & ND \\
\hline \multirow{3}{*}{ Propionic acid } & $1 \mathrm{st}$ & $\mathrm{ND}$ & ND & ND & ND & ND \\
\hline & 2 nd & $\mathrm{ND}$ & ND & $3.37 \pm 0.46^{\mathrm{ab}}$ & $6.84 \pm 6.33^{\mathrm{a}}$ & ND \\
\hline & $3 \mathrm{rd}$ & $\mathrm{ND}$ & $1.23 \pm 2.13^{\mathrm{b}}$ & $4.72 \pm 3.19^{\mathrm{ab}}$ & $4.74 \pm 0.88^{\mathrm{ab}}$ & $13.55 \pm 12.39^{\mathrm{a}}$ \\
\hline
\end{tabular}

${ }^{1)}$ Not detected.

${ }^{2}$ Mean $\pm \mathrm{SD}(\mathrm{n}=3)$ within each column followed by different letters is significantly different $(\mathrm{p}<0.05)$. 
군에서 각 $16.08 \mathrm{mg} / \mathrm{L}, 18.9 \mathrm{mg} / \mathrm{L}$ 로 가장 높게 검출되었다. 밀, 보리, 조의 2-3회 반복 발효가 진행될수록 citric acid의 성분이 점차 감소하는 특징을 보였다. 곡물 전체적으로 2-3 회 반복 발효가 진행될수록 lactic acid, acetic acid의 성분은 증가하며, succininc acid의 성분은 감소하는 특징을 보여주 었다. lactic acid와 acetic acid는 발효에 관여하는 미생물에 의해 주로 생성되며 이러한 유기산들은 ehtyl lactate나 ethyl acetate와 같은 향기성분으로 전환되는 것으로 연구되었다 (Choi와 Hong, 1999; Jørgensen 등, 2007). 따라서 고체발효 술덧 속에서 검출되는 lactic acid와 acetic acid같은 유기산은 고량주의 향기성분에 크게 영향을 미칠 수 있다.

\section{알코올 농도}

곡물 종류별 증류주의 알코올 함량을 측정하였다. 고체발 효 1회 발효 시 각 곡물의 알코올 함량은 Fig. 4(A)와 같다. 조를 사용하여 만든 증류주에서 $76.7 \%$ 로 가장 높은 알코올

(A)

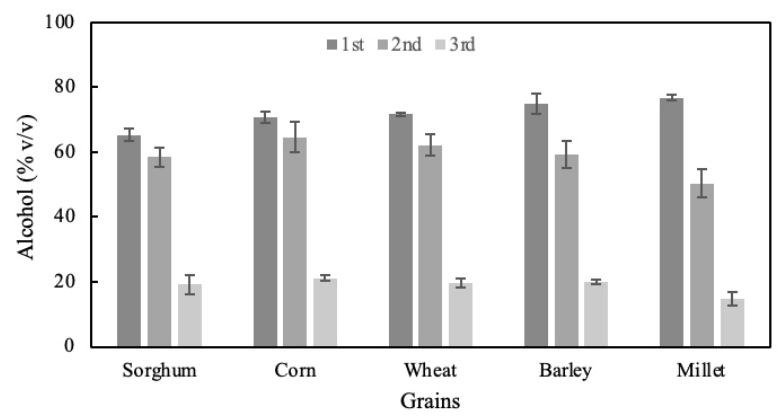

(B)

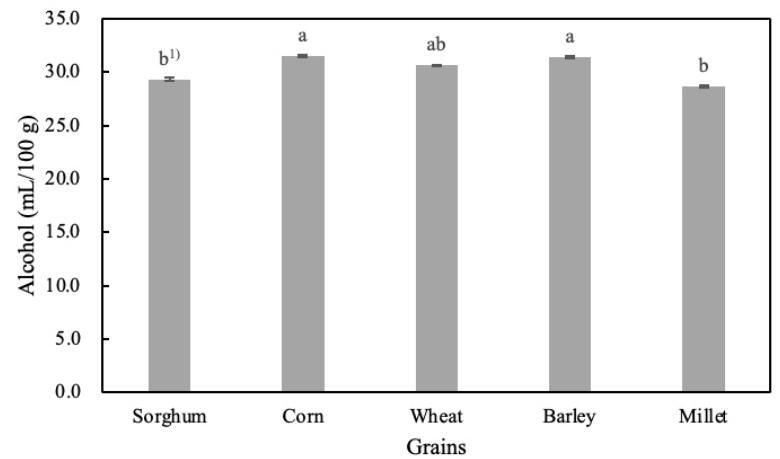

Fig. 4. Alcohol content in distilled liquid produced by the solid fermentation.

(A) Alcohol content produced according to the number of solid fermentation of grains. Data values were expressed as mean $\pm \mathrm{SD}(\mathrm{n}=3)$. (B) Total alcohol contents of the produced by solid fermentation of grains.

${ }^{\mathrm{P}} \mathrm{Mean} \pm \mathrm{SD}(\mathrm{n}=3$ ) within each column followed by different letters is significantly different $(\mathrm{p}<0.05)$
함량을 나타내며 수수를 사용하여 만든 증류주에서 $66.3 \%$ 로 가장 낮은 알코올 함량을 보여준다. 고체발효를 통해 총 3회 반복 발효를 진행하여 곡물에 포함된 전분을 전부 사용하여 알코올을 추출한 결과 Fig. 4(B)와 같다. 옥수수와 보리가 $31.5 \mathrm{~mL} / 100 \mathrm{~g}, 31.4 \mathrm{~mL} / 100 \mathrm{~g}$ 으로 가장 높고, 조를 사용한 고체발효 증류주가 $29.7 \mathrm{~mL} / 100 \mathrm{~g}$ 으로 가장 낮게 나타났다. 1 회 발효에서 조를 사용한 증류주에서 가장 높았지만 2회차 및 3 회차 반복 발효에서의 증류주는 알코올 함량이 가장 적 었고 전체적으로 옥수수와 보리의 알코올 수율이 가장 높았 다. 이는 조의 입자가 가장 작아 초기에는 발효가 잘되어 전 분의 알코올 변환이 쉬웠을 것으로 보이며 전체 알코올 수율 은 각 곡류 종류별 전분의 함량이 다르기에 각각의 수율에 차이가 있는 것으로 보인다.

\section{향기성분}

발효 중 휘발성 향기성분이 생성되며, 숙성을 통해 천천히 산성 향기성분이 생성되고(Margalit, 1997), 이러한 향기성분 은 술의 향미에 크게 영향을 미친다. 각 곡물종류별 증류주의 향기성분은 Table 5 와 같다. 향기성분으로는 수수를 사용한 고체발효 증류주에서 ethyl acetate, ethyl butyrate, ethyl lactate, acetic acid의 함량이 $82,750.29 \mathrm{mg} / \mathrm{L}, 878.98 \mathrm{mg} / \mathrm{L}$, $124.04 \mathrm{mg} / \mathrm{L}, 394.7 \mathrm{mg} / \mathrm{L}$ 로 가장 높고, 밀을 사용한 증류주 에서 ethyl caproate의 함량이 $38.23 \mathrm{mg} / \mathrm{L}$ 로 가장 높았다. 2차 반복발효에서 곡물 전체적으로 ethyl acetate, ethyl butyrate, ethyl caproate, ethyl lactate, ethyl palmitate의 함량이 증가하 였지만, 3 차 반복발효에서 다시 줄어드는 특징을 보였다. 수 수로 만든 고체발효 증류주에서 ethyl acetate의 성분의 함량 이 $70,910.33 \mathrm{mg} / \mathrm{L}$ 로 1 차 발효 시보다 약 $10,000 \mathrm{mg} / \mathrm{L}$ 가량 감소하는 특징을 보였다. 또한, 1 차 발효 시 밀에서 가장 높 은 함량을 나타내었던 ethyl caproate 성분이 2차 발효시에는 곡물 전체적으로 $19.89-23.85 \mathrm{mg} / \mathrm{L}$ 로 유의적인 차이가 나타 나지 않았다. 곡물 전체적으로 3 차 반복 발효 증류주의 향기 성분에서 acetic acid, propionic acid, butric acid, isovaleric acid, caproic acid의 성분은 점차 증가하는 특징을 보였다. 중 국의 고량주는 주요 esters로 ethyl acetate, ethyl caproate, ethyl lactate의 성분이 있으며 그 함량이 전체 esters의 $90 \%$ 이상을 차지한다(Fan 등, 2020). 따라서 각 곡물들 중 밀이 ethyl caproate의 함량이 가장 높고, 수수가 ethyl acetate, ethyl lactate의 함량이 가장 높다. 수수와 밀을 배합하여 술을 빚을 때 생산물의 상호보완성이 매우 좋다고 하였다(Xin 등, 2016). 고량주에 가장 적합한 향을 내기 위해 밀과 수수의 적 합한 배합을 통해 ethyl caproate의 함량을 높일 수 있을 것으 로 생각된다. 
Table 5. Volatile compounds in distilled liquid produced by the solid fermentation

\begin{tabular}{|c|c|c|c|c|c|c|}
\hline $\begin{array}{l}\text { Volatile } \\
\text { compound } \\
(\mathrm{mg} / \mathrm{L})\end{array}$ & $\begin{array}{l}\text { The number of } \\
\text { fermentation } \\
\text { times }\end{array}$ & Sorghum & Corn & Wheat & Barley & Millet \\
\hline \multirow{3}{*}{ Ethyl acetate } & $1 \mathrm{st}$ & $82,750.3 \pm 26,549.8^{\mathrm{al})}$ & $42,353.2 \pm 9,912.2^{\mathrm{b}}$ & $24,280.7 \pm 3,012.9^{b}$ & $21,168.7 \pm 4,634.8^{b}$ & $17,678.3 \pm 1,709.8^{b}$ \\
\hline & 2nd & $70,910.3 \pm 52,378.2$ & $61,845.9 \pm 24,632$ & $53,234.4 \pm 15,989.5$ & $38,082.8 \pm 13,280.4$ & $53,758.1 \pm 29,280.8$ \\
\hline & $3 \mathrm{rd}$ & $23,902.1 \pm 11,120.7$ & $16,002.5 \pm 6,101.9$ & $15,118.9 \pm 4,129.7$ & $19,348.5 \pm 5,705.7$ & $13,734.4 \pm 9,851.4$ \\
\hline \multirow{3}{*}{ Ethyl butyrate } & $1 \mathrm{st}$ & $879 \pm 79.5^{\mathrm{a}}$ & $665 \pm 117^{\mathrm{bc}}$ & $675.3 \pm 11.9^{\mathrm{bc}}$ & $591.3 \pm 13.9^{c}$ & $720.9 \pm 18.7^{b}$ \\
\hline & 2 nd & $1,114.5 \pm 186.49^{b c}$ & $1,358.5 \pm 412.2^{\mathrm{ab}}$ & $960.9 \pm 76.8^{\mathrm{ba}}$ & $763 \pm 126.3^{\mathrm{c}}$ & $1,669 \pm 105.37^{\mathrm{a}}$ \\
\hline & $3 \mathrm{rd}$ & $1,976.2 \pm 868^{\mathrm{b}}$ & $4,473.7 \pm 479.5^{\mathrm{a}}$ & $2,471.1 \pm 768.6^{\mathrm{b}}$ & $2,406.3 \pm 648.8^{b}$ & $1,772 \pm 556.2^{\mathrm{b}}$ \\
\hline \multirow{3}{*}{ Ethyl caproate } & $1 \mathrm{st}$ & $28.3 \pm 0.7^{b}$ & $22.1 \pm 0.3^{d}$ & $38.2 \pm 1.5^{\mathrm{a}}$ & $26.1 \pm 0.9^{c}$ & $29.9 \pm 0.9^{b}$ \\
\hline & 2nd & $19.9 \pm 2.9^{\mathrm{a}}$ & $19 \pm 2.4^{\mathrm{a}}$ & $22 \pm 3.4^{\mathrm{a}}$ & $20.5 \pm 3.7^{\mathrm{a}}$ & $23.8 \pm 5^{\mathrm{a}}$ \\
\hline & $3 \mathrm{rd}$ & $9.0 \pm 8.8$ & $3.1 \pm 5.4$ & $7.1 \pm 6.2$ & $6.9 \pm 6$ & $\mathrm{ND}^{2)}$ \\
\hline \multirow{3}{*}{ Ethyl lactate } & $1 \mathrm{st}$ & $124 \pm 27.3^{\mathrm{a}}$ & $77.6 \pm 14.4^{\mathrm{bc}}$ & $92 \pm 16.8^{b}$ & $56.1 \pm 1.3^{\mathrm{cd}}$ & $47.3 \pm 3.7^{\mathrm{d}}$ \\
\hline & 2nd & $202.4 \pm 34.4^{\mathrm{a}}$ & $147.3 \pm 38.6^{\mathrm{ab}}$ & $79.6 \pm 18.2^{\mathrm{c}}$ & $101.2 \pm 34.7^{\mathrm{bc}}$ & $204.3 \pm 24.7^{\mathrm{a}}$ \\
\hline & $3 \mathrm{rd}$ & $176.5 \pm 62.5$ & $164.3 \pm 17.2$ & $117.9 \pm 40.7$ & $135.4 \pm 25.2$ & $132.3 \pm 19.5$ \\
\hline \multirow{3}{*}{ Ethyl palmitate } & $1 \mathrm{st}$ & $108.5 \pm 15.5^{\text {bc }}$ & $121.69 \pm 8.9^{\mathrm{ab}}$ & $126.6 \pm 5.6^{\mathrm{ab}}$ & $136.1 \pm 15.9^{\mathrm{a}}$ & $94.6 \pm 9.5^{\mathrm{c}}$ \\
\hline & 2 nd & $126.3 \pm 12.3$ & $139.3 \pm 4.8$ & $127.3 \pm 18.3$ & $122.1 \pm 9.535$ & $131.4 \pm 42.9$ \\
\hline & $3 \mathrm{rd}$ & $43.2 \pm 74.9$ & ND & ND & ND & ND \\
\hline \multirow{3}{*}{ Acetic acid } & $1 \mathrm{st}$ & $394.7 \pm 84.6^{\mathrm{a}}$ & $197.4 \pm 58.3^{\mathrm{b}}$ & $118.6 \pm 18.1^{b c}$ & $61.6 \pm 23.7^{\mathrm{c}}$ & $52.2 \pm 12.4^{\mathrm{c}}$ \\
\hline & 2 nd & $1,379.9 \pm 1,118.34$ & $579.5 \pm 216.6$ & $525.3 \pm 227$ & $402.9 \pm 116$ & $1,573.5 \pm 1,309.4$ \\
\hline & $3 \mathrm{rd}$ & $4,671.8 \pm 6,374.8$ & $2,540.4 \pm 426.2$ & $2,639.7 \pm 810$ & $3,288.9 \pm 1,230.3$ & $2,882.9 \pm 1,656.7$ \\
\hline \multirow{3}{*}{ Propionic acid } & $1 \mathrm{st}$ & $43.9 \pm 5.8^{\mathrm{a}}$ & ND & ND & ND & ND \\
\hline & 2nd & $97 \pm 10.7^{\mathrm{b}}$ & $61.6 \pm 29.7^{\mathrm{b}}$ & $13.6 \pm 236^{\mathrm{c}}$ & ND & $180.4 \pm 26.5^{\mathrm{a}}$ \\
\hline & $3 \mathrm{rd}$ & $204.7 \pm 101.3^{\mathrm{b}}$ & $387.4 \pm 102.6^{\mathrm{ab}}$ & $525.6 \pm 101.8^{\mathrm{a}}$ & $632.9 \pm 176.9^{\mathrm{a}}$ & $549 \pm 158.8^{\mathrm{a}}$ \\
\hline \multirow{3}{*}{ Butyric acid } & $1 \mathrm{st}$ & ND & ND & ND & ND & ND \\
\hline & 2nd & ND & ND & ND & ND & $20.8 \pm 18.02$ \\
\hline & $3 \mathrm{rd}$ & $24.5 \pm 21.7$ & $29.1 \pm 26.5$ & $79.4 \pm 99.3$ & $36.6 \pm 4.3$ & $51.6 \pm 16.4$ \\
\hline \multirow{3}{*}{ Isovaleric acid } & $1 \mathrm{st}$ & $37.6 \pm 0.6^{\mathrm{a}}$ & $35.1 \pm 2.6^{\mathrm{b}}$ & $38.3 \pm 1.4^{\mathrm{a}}$ & $\mathrm{N} / \mathrm{D}$ & $\mathrm{N} / \mathrm{D}$ \\
\hline & 2nd & $67.9 \pm 26.2^{\mathrm{ab}}$ & $55.8 \pm 32.2^{\mathrm{ab}}$ & $32.8 \pm 1.3^{\mathrm{b}}$ & $37.3 \pm 3.1^{\mathrm{b}}$ & $89.5 \pm 25.5^{\mathrm{a}}$ \\
\hline & $3 \mathrm{rd}$ & $60.7 \pm 19.5$ & $98.6 \pm 72.5$ & $98.3 \pm 59.7$ & $88.5 \pm 8.5$ & $134.1 \pm 80.4$ \\
\hline \multirow{3}{*}{ Caproic acid } & $1 \mathrm{st}$ & ND & ND & ND & ND & ND \\
\hline & 2nd & $45.5 \pm 39.4^{\mathrm{a}}$ & ND & ND & ND & ND \\
\hline & $3 \mathrm{rd}$ & $69.6 \pm 2.2$ & $69.83 \pm 2.1$ & $69.77 \pm 1.3$ & $68.7 \pm 0.8$ & $46.2 \pm 40.1$ \\
\hline
\end{tabular}

${ }^{1)}$ Mean \pm SD $(n=3)$ within each line followed by different letters is significantly different $(\mathrm{p}<0.05)$.
${ }^{2)}$ Not detected. 


\section{요 약}

본 연구에서는 한국형 고량주 개발을 위해 국내산 곡물 원 료에 따른 고량주의 품질 특성을 연구하였다. 국내에서 생산 되는 곡물 종류 5 종(수수, 옥수수, 밀, 보리, 조)을 사용하여 고체발효를 진행하였고, 총 3 회에 걸쳐 재 발효를 실시하여 품질 및 특성을 조사하였다. 각 곡물 모두 발효 전, 후 $\mathrm{pH}$ 가 감소하여 안정적 발효가 진행됨을 알 수 있으며 그 중 수수를 사용한 고체발효 술덧에서의 $\mathrm{pH}$ 가 4.65로 가장 낮게 분석되 어, 유기산이 많이 생성되었음을 알 수 있다. 총산은 유기산 생성과, 휘발성 향기성분에 영향을 미치며, 수수를 사용한 고 체발효 술덧에서 $0.77 \%$ 로 가장 높고, 보리가 $0.51 \%$ 로 가장 낮게 분석되었다. 유리당 분석결과 총 3 회의 재 발효 시 당이 전부 소모되어 유리당이 검출되지 않아 곡류의 당분이 모든 알코올로 전환되었음을 확인하였다. 유기산 분석결과 수수를 사용하여 만든 고체발효 술덧에서 lactic acid, acetic acid가 $116.84,143.1$ 로 가장 높았으며, 이는 향기성분인 ethyl lactate, ethyl acetate 생성에 영향을 주었다. 각 곡물 종류별 알코올 총량은 옥수수, 보리를 각각 사용하여 만든 고체발효 증류주 에서 $31.5 \mathrm{~mL} / 100 \mathrm{~g}, 31.4 \mathrm{~mL} / 100 \mathrm{~g}$ 으로 가장 높게 분석되 었다. 수수를 사용한 고체발효 증류주에서 고량주의 주요향 기성분으로 알려진 ethyl acetate, ethyl butyrate, ethyl lactate 성분이 다른 곡물들에 비해 다량 검출되는 결과가 나타났고, 밀을 사용한 고체발효 증류주에서 ethyl caproate 성분이 가장 높게 검출되었다. 따라서 곡물 원료를 다르게 하여 분석하였 을 때 수수를 사용하여 만든 고체발효 증류주가 다른 곡물에 비해 고량주의 주요 향기성분을 다량 함유하여 한국형 고량주 로서 적합한 원료로서 판단되지만, 밀의 적합한 배합을 통해 더욱 ethyl caproate 함량을 높일 수 있을 것으로 생각된다.

\section{감사의 글}

본 연구는 농촌진흥청 연구개발사업(과제번호: PJ015294)의 지원에 의해 이루어진 것으로, 연구비 지원에 감사드립니다.

\section{Conflict of interests}

The authors declare no potential conflict of interest.

\section{ORCID}

Hwa-Rang Seo

Seok-Tae Jeong

Heui-Yun Kang
https://orcid.org/0000-0002-9616-360X

https://orcid.org/0000-0001-9997-2763

https://orcid.org/0000-0001-5479-7973
Sun-Il Yun

https://orcid.org/0000-0001-7686-791X

\section{References}

Choi Ji, Hong WH. Separation characteristics of lactic acid by batch reactive distillation. Korean J Biotechnol Bioeng, 14, 220-224 (1999)

Fan B, Xiang L, Yu Y, Chen X, Wu Q, Zhao K, Zheng Q. Solid-state fermentation with pretreated rice husk: Green technology for the distilled spirit (Baijiu) production. Environ Sci Technol, 20, 101049 (2020)

Xing Lin, H, DeLiang W, Wu Jiu Z, ShiRu J. The production of the Chinese baijiu from sorghum and other cereals. J Inst Brew, 123, 600-604 (2017)

Jorgensen B, Christiansen SE, Thomsen MLD, Christensen $\mathrm{CH}$. Aerobic oxidation of aqueous ethanol using heterogeneous gold catalysts: Efficient routes to acetic acid and ethyl acetate. J Catal, 251, 332-337 (2007)

KATI. https:/www.kati.net/statistics/monthlyPerformanceBy Product.do (2021) (accessed September 23 2021)

Kim CW, Kang JE, Jeong ST, Choi HS. Physicochemical properties of non-sterilized makgeolli prepared using different fermentation starters and storage conditions. J East Asian Soc Diet Life, 27, 629-634 (2017)

Kim HJ, Jo JS. Studies on the production of vinegar from Koryangju Distillers' Grain. Kor J Appl Microbiol Bioeng, 9, 191-196 (1981)

Kim JY, Yi YH. pH, acidity, color, amino acids, reducing sugars, total sugars, and alcohol in puffed millet powder containing millet takju during fermentation. Korean J Food Sci Technol, 42, 727-732 (2010)

Lee DH, Lee YS, Cho CH, Park IT, Kim HD, Kim JH, Ahn BH. The qualities of liquor distilled from Ipguk (Koji) or Nuruk under reduced or atmospheric pressure. Korean J Food Sci Technol, 46, 25-32 (2014)

Lee HS, Park CS, Choi JY. Quality characteristics of the mashes of Takju prepared using different yeasts. Korean J Food Sci Technol, 42, 56-62 (2010)

Lee JK, Mun SH, Bae GH, Kim JH, Choi HS, Kim TH, Jeong C. Distilled Spirits. Gwangmungak Publishing Co., Paju, Korea, p 269-271 (2015)

Lee TJ, Hwang DY, Lee CY, Son HJ. Changes in yeast cell number, total acid and organic acid during production and dis-tribution processes of makgeolli, traditional alcohol of 
Korea. Korean J Microbiol, 45, 391-396 (2009)

Liu H, Sun B. Effect of fermentation processing on the flavor of baijiu. J Agric Food Chem, 66, 5425-5432 (2018)

Margalit Y. Concept in Wine Chemistry. Wine Appreciation Guild Publishing Co., San Francisco, USA, p 15-147 (1997)

National Legal Information Center. Liquor analysis regulations. https://www.law.go.kr/LSW/admRulLsInfoP.do?admRul Seq=2100000100372\#J4:0 (2017) (accessed September 23 2021)

Park YD, Bae EJ, Choi JS, Kim HS, Kim CW, Jeong ST, Choi HS. Quality characteristics of sterilized makgeollies brewed with different materials. J East Asian Soc Diet
Life, 27, 658-667 (2017)

Song CS, Ju HM, Kim JM. Effects of isoamyl acetate production in Makgeolli according to fermentation conditions. J Life Sci, 30, 162-168 (2020)

Xin C, Xu L, Yu P, Zheng Y, Zhao J, Shandong B. Brief introduction of the role of grain raw materials in the brewing of liquor. China J Wine, 5, 44-48 (2016)

Yu A, Yan X, Dong W. Analysis of influence on different raw materials on volatile aroma compounds of ciders. J Sci Agric Sin, 39, 786-791 (2006)

Zamora MC, Guirao M. Analysing the contribution of orally perceived attributes to the flavor of wine. J Food Qual Prefer, 13, 275-283 (2002) 